\title{
ANALISIS KORELASI LIPATAN KULIT (TLK) DENGAN INDEKS MASSA TUBUH (IMT) REMAJA PEREMPUAN MADURA DI SUMENEP
}

\author{
Anung Putri Illahika ${ }^{1}$ \\ ${ }^{1}$ Bagian Anatomi Fakultas Kedokteran Universitas Muhammadiyah Malang \\ Jl.Sidoyoso 2 gg.1 no.4 Surabaya 60143, \\ anungputri113@gmail.com
}

\begin{abstract}
ABSTRAK
Latar belakang dan Tujuan penelitian: Tumbuh kembang merupakan proses yang berkesinambungan dalam proses mencapai dewasa, termasuk tahap remaja. Permasalahan yang sering dihadapi adalah peruubhan fisik. Perubahan fisik remaja perempuan yang sangat tampak adalah meningkatnya tinggi dan berat badan yang mempengaruhi Indeks Massa Tubuh (IMT). Salah satu komposisi tubuh yang dapat diukur adalah Tebal Lipatan Kulit (TLK), yang merupakan bagian dari massa lemak tubuh. Perbedaan lokasi memungkinkan adanya perbedaan TLK pada individu meskipun etnis yang sama. Tujuan dari penelitian ini adalah untuk mengetahui hubungan TLK dengan Indeks Massa Tubuh (IMT) remaja perempuan etnis Madura di Sumenep.

Metode: Penelitian ini merupakan studi korelasi dan mengambil sampel dari siswa SMA berjumlah 40 memiliki di kisaran 17-20 tahun yaitu siswi SMA Negeri 1 Sumenep. TLK diukur di bagian sinistra pada biceps, triceps, subscapula dan suprailiaca. IMT adalah suatu indeks yang didapatkan dari hasil pembagian $\mathrm{BB}$ dengan $\mathrm{TB}^{2}$. Hasil pengukuran dinyatakan dalam $\mathrm{kg} / \mathrm{m}^{2}$.Semua data yang diperoleh akan dianalisis menggunakan uji korelasi spearmen.

Hasil penelitian: Hasil analisis menunjukkan terdapat hubungan antara indeks massa tubuh dengan tebal lipatan kulit. Nilai signifikansi TLK ekstremitas adalah 0,002 dengan besar korelasi 0,485. Nilai signifikansi TLK trunkus adalah 0,042 dengan besar korelasi -0,323. Artinya semakin tinggi IMT maka semakin menurun TLK Extremitas.

Simpulan: Terdapat hubungan antara indeks massa tubuh dengan tebal lipatan kulit remaja perempuan Madura di Sumenep.
\end{abstract}

Kata Kunci: TLK, IMT, etnis, remaja, perempuan

\section{Pendahuluan}

Remaja merupakan suatu tahapan dalam tumbuh kembang. Remaja tumbuh pada kecepatan yang bervariasi, sehingga terjadi variasi ukuran dan bentuk yang pada masa anak-anak masih belum tampak. Perubahan fisik remaja perempuan yang sangat tampak adalah meningkatnya tinggi dan berat badan ${ }^{1}$.

Tinggi dan berat badan merupakan dua hal yang mempengaruhi indeks massa tubuh (IMT) secara tidak langsung berhubungan dengan bentuk tubuh. Hal tersebut sering menjadi masalah yang penting bagi sebagian masyarakat, termasuk remaja perempuan. Masalah yang dimaksud dimulai dari masalah kesehatan sampai penampilan. Hal yang sependapat juga ditemukan pada hasil penelitian di Iran dengan menggunakan sampel remaja perempuan, di mana menunjukkan bahwa penimbunan lemak di trunkus, besarnya IMT dan lingkar perut, sebagai prediksi faktor predisposisi penyakit metabolik dan kardiovaskuler pada remaja perempuan ${ }^{2}$.

American College of Sports Medicine (ACSM) menyatakan bahwa Tebal Lipatan Kulit (TLK) merupakan suatu pengukuran persen lemak tubuh dengan akurasi 98\%3 Pengukuran bisa dilakukan hanya pada 4 lokasi lipatan kulit yaitu daerah triceps, biceps, subscapular dan suprailiaca ${ }^{4}$.

Penelitian distribusi lemak pada etnis Madura belum pernah diteliti, sedangkan salah satu keunikan etnis Madura adalah jumlah penduduk di luar Pulau Madura lebih besar (52,19\%) daripada penduduk di Pulau Madura itu sendiri (47\%). Penduduk etnis Madura yang berada di daerah yang berbeda memungkinkan mendapatkan pengaruh lingkungan yang berbeda. Penelitian ini bertujuan untuk mengetahui 
hubungan TLK dengan IMT remaja perempuan etnis Madura di Surabaya.

\section{Metode Penelitian}

Penelitian ini merupakan studi komparasi dengan mengambil sampel berjumlah 40 siswi SMA yang mempunyai usia pada rentang 17-20 tahun yaitu siswi SMA Muhammadiyah 1 Surabaya. Data akan diambil adalah TLK dengan cara pengukuran menggunakan alat skinfold caliper dan diukur di bagian sinistra pada 4 tempat yaitu biceps, triceps, subscapula dan suprailiaca. Hasil pengukuran tersebut mempunyai skala numerik dengan satuan milimeter (mm). Indeks massa tubuh (IMT) adalah suatu indeks yang didapatkan dari hasil pembagian $\mathrm{BB}$ dengan $\mathrm{TB}^{2}$. Hasil pengukuran dinyatakan dalam $\mathrm{kg} / \mathrm{m}^{2}$.

Semua data yang diperoleh akan dianalisis menggunakan uji korelasi Spearmen.

\section{Hasil Penelitian}

Tebal Lipatan Kulit (TLK) pada penelitian ini diukur pada 4 tempat: triceps, biceps, subscapular, suprailiaca. Data dari triceps dan biceps dijumlahkan untuk mendapatkan data TLK pada extremitas, sedangkan data dari subscapular dan suprailiaca dijumlahkan untuk mendapatkan data TLK pada trunkus. Penjumlahan TLK tersebut bertujuan untuk membedakan distribusi lemak sentral (trunkus) dan perifer (extremitas).

Rata-rata TLK ekstremitas paling besar didapatkan pada IMT kategori resiko obes sedangkan rata-rata TLK trunkus paling besar didapatkan pada IMT kategori kurang, namun dari diagram di atas menunjukkan bahwa besarnya nilai TLK tidak mengikuti besar nilai dari IMT.

Berdasarkan hasil uji korelasi spearman diperoleh nilai sig $=0.002$ yang menunjukkan bahwa terdapat hubungan antara IMT dan TLK Ekstremitas di wilayah Sumenep. Besarnya hubungan adalah -0,485 yang masuk dalam rentang cukup kuat. Arah korelasi adalah negative yang artinya jika IMT semakin tinggi maka TLK Extremitas semakin menurun.

Berdasarkan hasil uji korelasi spearman diperoleh nilai sig $=0.002$ yang menunjukkan bahwa terdapat hubungan antara IMT dan TLK Ekstremitas di wilayah Sumenep. Besarnya hubungan adalah -0,485 yang masuk dalam rentang cukup kuat. Arah korelasi adalah negative yang artinya jika IMT semakin tinggi maka TLK Extremitas semakin menurun.

\section{Pembahasan}

Berdasarkan hasil rerata TLK diatas, menunjukkan bahwa hasil TLK pada remaja perempuan etnis Madura pada penelitian ini lebih rendah bila dibandingkan dengan remaja perempuan etnis Jawa dan Cina yang dapat dilihat dari hasil penelitian ${ }^{4}$. Hal ini berbeda dengan hasil penelitian oleh Guricci (1999) yang menunjukkan tidak ada perbedaan ketebalan lemak subkutan antara 2 kelompok yang berbeda asal keturunannya ${ }^{6}$.

Berdasarkan analisis data menunjukkan bahwa ada hubungan antara TLK dengan IMT. Hasil ini sesuai dengan banyak penelitian lain, salah satunya adalah penelitian Anggraini, 2007 pada wanita obese dan non-obese yang menyimpulkan terdapat hubungan antara IMT dengan TLK Triceps dan subscapula ${ }^{7}$.

Asal keturunan ini erat kaitannya dengan faktor genetik yang merupakan salah satu faktor internal yang dapat mempengaruhi komposisi tubuh, tidak menutup kemungkinan bahwa perbedaan distribusi lemak subkutan juga terjadi akibat faktor eksternal seperti nutrisi, kultur dan aktivitas fisik, namun hal tersebut tidak diteliti dalam penelitian kali ini. 
Menurut teori, TLK merupakan salah satu komponen pengukuran yang dapat menunjukkan massa lemak tubuh. Massa lemak dihitung sebagai persentase terhadap berat badan dengan menjumlah 4 daerah pengukuran ${ }^{4}$. Hasil penelitian ini menunjukkan bahwa nilai IMT yang tinggi belum tentu karena jarigan lemak tapi dapat juga karena jaringan otot.

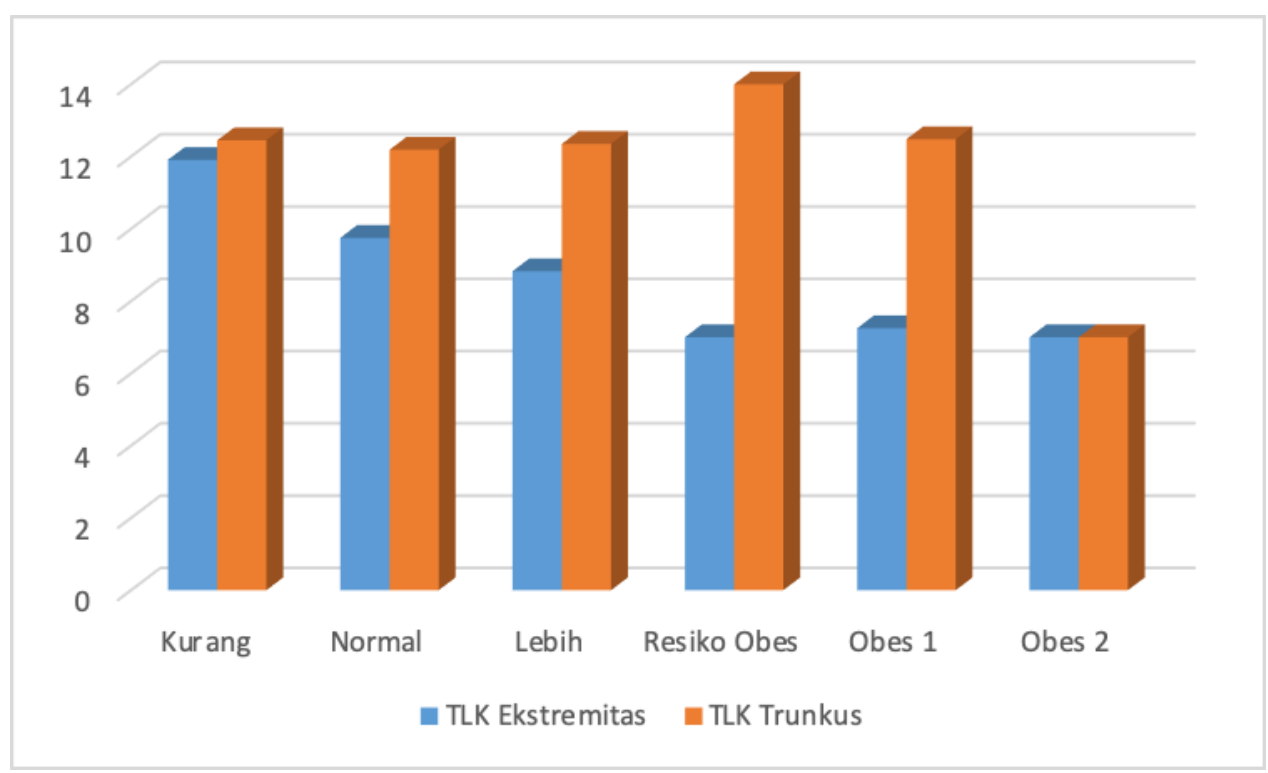

Gambar 1. Rata-rata tebal lipatan kulit ekstremitas dan trunkus untuk setiap IMT

Tabel 1. Hasil uji Korelasi Spearmen TLK Ekstremitas

Correlations $^{\mathrm{a}}$

\begin{tabular}{|c|c|c|c|c|}
\hline & & & IMT & $\begin{array}{c}\text { SFT_EXTREMI } \\
\text { TAS } \\
\end{array}$ \\
\hline \multirow{6}{*}{ Spearman's rho } & \multirow{3}{*}{ IMT } & Correlation Coefficient & 1.000 & $-.485^{* *}$ \\
\hline & & Sig. (2-tailed) & & .002 \\
\hline & & $\mathrm{N}$ & 40 & 40 \\
\hline & \multirow{3}{*}{ SFT_EXTREMITAS } & Correlation Coefficient & $-.485^{* *}$ & 1.000 \\
\hline & & Sig. (2-tailed) & .002 & \\
\hline & & $\mathrm{N}$ & 40 & 40 \\
\hline
\end{tabular}

**. Correlation is significant at the 0,01 level (2 tailed)

a. Lokasi $=$ Sumenep

Tabel 2. Hasil uji Korelasi Spearmen TLK Trunkus

\begin{tabular}{|rl|r|r|}
\hline \multicolumn{7}{c|}{ Correlations $^{\mathbf{a}}$} \\
\hline & & IMT & SFT_TRUNKU \\
S
\end{tabular}

**. Correlation is significant at the 0,05 level (2 tailed)

a. Lokasi $=$ Sumenep

\section{Referensi}

1. Santrock. 2003. John W. Adolescence. Perkembangan Remaja. Edisi Keenam. Jakarta: Erlangga

2. Mirhosseini, N.Z., Shahar, S., Mobarhan, M.G., Parizadeh, M.R., Yusoff, B.A.M. and Shaker, M.T. 2012. Body Fat Distribution and Its Association with Cardiovascular Risk
Factors in adolescent Iranian Girls. Iran J Pediatr 22(2). p 197-204.

3. Quinn, E. 2010. Calculate Body Fat by Measuring Skionfolds: Does measuring skinfold thickness determine body fat percentage? : ACSM's Guidelines for Exercise Testing and Prescription.

4. Budiman, I. 2008. Validitas pengukuran lemak tubuh yang menggunakan skinfold caliper di 2, 3, 4, 7 tempat 
terhadap cara bod pod. Jurnal kedokteran Maranatha 7(2). p 100-109.

5. Sakina. 2013. Perbedaan Distribusi Lemak Subkutan, Ukuran dan Indeks Antropometri antara Populasi Cina dan Jawa Kelas X-Xi di SMAK St. Hendrikus dan SMA Muhammadiyah 2 Surabaya. Surabaya: Universitas Airlangga.

6. Guricci, Syafri., Hatriyanti, Yayuk., Hautvast, Joseph., Deurenberg, Paul. 2002. Prediction of extracellular water and total body water by multifrequency bio-electrical impedance in a Southeast Asian population. Asia Pasific Journal of Clinical Nutrition. https://doi.org/10.1046/j.14406047.1999.00088.x

7. Anggraini, Windi. 2007. Pengaruh dan Hubungan BMI (Body Mass Index) Dengan TLK (Tebal Lipatan Kulit) Triceps dan Subscapula. http://repository.maranatha.edu 